Check for updates

Cite this: Mater. Adv., 2021,

2, 1320

Received 28th October 2020

Accepted 7th January 2021

DOI: 10.1039/d0ma00845a

rsc.li/materials-advances

\title{
Alkylamine screening and zinc doping of highly luminescent 2D tin-halide perovskites for LED lighting $\dagger$
}

\author{
Yao Liu, $\ddagger^{\mathrm{a}}$ Aifei Wang, (D) $\ddagger \S^{\mathrm{a}}$ Jiajing Wu, ${ }^{\mathrm{a}}$ Chuying Wang, ${ }^{\mathrm{a}}$ Ziliang $\mathrm{Li},{ }^{\mathrm{b}}$ Guangcai $\mathrm{Hu},{ }^{\mathrm{a}}$ \\ Shiqi Sui, (D) ${ }^{a}$ Jia-Xin She, ${ }^{c}$ Wen Meng, ${ }^{a}$ Weiqiang $\mathrm{Li}^{\mathrm{D}}{ }^{\mathrm{c}}$ and Zhengtao Deng (iD) *a
}

\begin{abstract}
In recent years, two-dimensional (2D) layered tin halide perovskites have attracted much attention due to their excellent luminescence properties compared with their three-dimensional (3D) analogs. Here, we synthesized 2D perovskites of the form $\left(\mathrm{RNH}_{3}\right)_{2} \mathrm{SnBr}_{4}$ through a facile hot-injection approach without the use of toxic tri-n-octylphosphine (TOP) as the solvent. We found that these compounds have strong photoluminescence (PL) emission with high $\mathrm{PL}$ quantum yields (QY) of $35 \%$ $\left(\left(\mathrm{C}_{6} \mathrm{H}_{13} \mathrm{NH}_{3}\right)_{2} \mathrm{SnBr}_{4}\right), 82 \%\left(\left(\mathrm{C}_{8} \mathrm{H}_{17} \mathrm{NH}_{3}\right)_{2} \mathrm{SnBr}_{4}\right), 60 \%\left(\left(\mathrm{C}_{12} \mathrm{H}_{25} \mathrm{NH}_{3}\right)_{2} \mathrm{SnBr}_{4}\right)$ and $50 \%\left(\left(\mathrm{C}_{18} \mathrm{H}_{35} \mathrm{NH}_{3}\right)_{2} \mathrm{SnBr}_{4}\right)$. Among them, $\left(\left(\mathrm{C}_{6} \mathrm{H}_{13} \mathrm{NH}_{3}\right)_{2} \mathrm{SnBr}_{4}\right)$ was synthesized for the first time; however, $\left(\mathrm{C}_{18} \mathrm{H}_{36} \mathrm{NH}_{3}\right)_{2} \mathrm{SnBr}_{4}$ perovskites showed the best stability with a PL QY decrease of less than $1 \%$ after 30 days under ambient air and humidity conditions. In addition, other $2 \mathrm{D}\left(\mathrm{C}_{8} \mathrm{H}_{17} \mathrm{NH}_{3}\right)_{2} \mathrm{SnX} \mathrm{X}_{4}(\mathrm{X}=\mathrm{Br}$, I, or mixture) perovskites were prepared by adjusting the halide ratio, resulting in spectral tunability from yellow to red. Interestingly, through $\mathrm{Zn}^{2+}$ doping, the morphology became more uniform, and the $\mathrm{PL}$ stability was significantly improved. Finally, we used $\mathrm{Zn}^{2+}$-doped $\left(\mathrm{C}_{8} \mathrm{H}_{17} \mathrm{NH}_{3}\right)_{2} \mathrm{SnBr}_{4}$ yellow phosphor to fabricate UVpumped yellow LEDs. We expect these $2 \mathrm{D}$ perovskites to be promising phosphors in future solid-state lighting and display technologies.
\end{abstract}

\section{Introduction}

Lead halide perovskites (LHPs) have been used in many fields including light-emitting diode (LED) devices, ${ }^{1}$ solar cells ${ }^{2,3}$ and television displays ${ }^{4}$ due to their superior optical properties ${ }^{1,5}$ and low-cost preparation. ${ }^{6}$ Although many advances have been made in lead halide perovskites, their toxicity to humans and long-term pollution to the environment remain to be addressed. ${ }^{7,8}$ Thus, lead-free halide perovskites (LFHPs) with similar optoelectronic properties to LHPs have been broadly studied. ${ }^{9-14}$ Tin-halide perovskites have drawn a lot of attention for substitution of lead in all optoelectronic applications. ${ }^{15-17}$

\footnotetext{
${ }^{a}$ College of Engineering and Applied Sciences, Nanjing University, Nanjing, Jiangsu 210023, China. E-mail: dengz@nju.edu.cn

${ }^{b}$ Department of Electrical and Computer Engineering, University of Toronto, 10 King's College Road, Toronto, Ontario M5S 3G4, Canada ${ }^{c}$ State Key Laboratory for Mineral Deposits Research, School of Earth Sciences and Engineering, Nanjing University, Nanjing, Jiangsu, 210023, P. R. China

$\dagger$ Electronic supplementary information (ESI) available: Fig. S1-S12 and Tables S1-S3. CCDC. For ESI and crystallographic data in CIF or other electronic format see DOI: $10.1039 /$ d0ma00845a

\$ These two authors contributed equally to this work.

$\S$ Current address: Institute of Advanced Materials (IAM), Nanjing Tech University (NJ Tech), 5 Xinmofan Road, Nanjing 210009, P. R. China.
}

However, owing to the lack of an inert pair effect as in $\mathrm{Pb}^{2+}$, divalent $\mathrm{Sn}$ is easily oxidized from the +2 to +4 state, causing deep defects in perovskites. The instability of tin-halide perovskites will seriously affect the device performance, even under trace amounts of water and oxygen in the glovebox. ${ }^{18-20}$

A series of strategies to overcome the instability of tin-halide perovskites have been developed. Deng et al. successfully synthesized $\mathrm{Cs}_{2} \mathrm{SnI}_{6}$ nanocrystals and applied them to fabricate field effect transistors (FETs) via direct replacement of $\mathrm{Sn}^{2+}$ with $\mathrm{Sn}^{4+} .{ }^{21}$ Bi-doped $\mathrm{Cs}_{2} \mathrm{SnCl}_{6}$ bulk crystals with a PL QY near $80 \%$ were reported to emit deep-blue light, which also showed improved stability. ${ }^{22}$ In addition to direct substitution of $\mathrm{Sn}^{2+}$, introducing hydrophobic organic molecules into the crystal structure is another way to protect $\mathrm{Sn}^{2+}$ from water and oxygen. Recently, two-dimensional (2D) layered tin-halide perovskites with the formula of $\left(\mathrm{R}-\mathrm{NH}_{3}\right)_{2} \mathrm{~A}_{n-1} \mathrm{Sn}_{n} \mathrm{X}_{3 n+1}(\mathrm{R}=$ alkyl chains; $\mathrm{A}=\mathrm{Cs}^{+}, \mathrm{MA}^{+}, \mathrm{FA}^{+} ; \mathrm{X}=\mathrm{Cl}^{-}, \mathrm{Br}^{-}, \mathrm{I}^{-}$) have attracted much attention. ${ }^{10,23}$ Such $2 \mathrm{D}$ tin-halide perovskites showed good photoluminescence and electroluminescence as well as improved resistance to air and moisture ${ }^{10,15,24}$ compared with homologous three-dimensional (3D) $\mathrm{ASnX}_{3}$ perovskites. For instance, 2D (PEA) ${ }_{2} \mathrm{SnI}_{4}$ thin films were reported to exhibit superior photoluminescence and air stability over bulk $\mathrm{CH}_{3} \mathrm{NH}_{3} \mathrm{SnI}_{3}$ perovskites, which were used as emitting layers in 


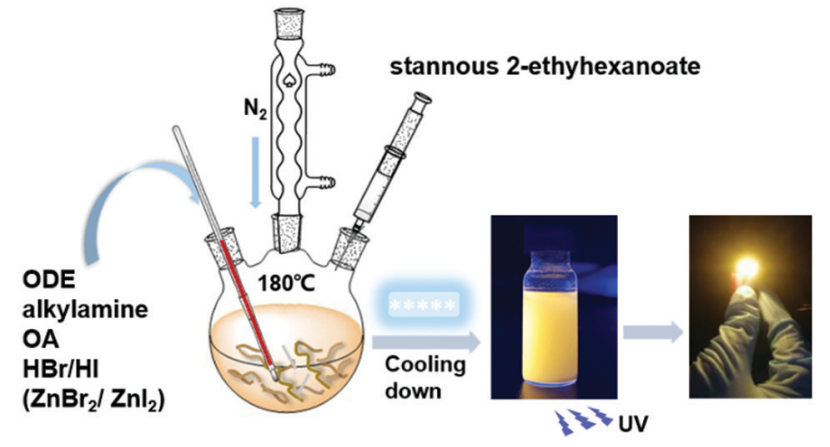

Scheme 1 Schematic diagram of the synthesis of the 2D $\left(\mathrm{RNH}_{3}\right)_{2} \mathrm{SnX}_{4}$ perovskites by a hot-injection method.

LEDs. ${ }^{24}$ Ning's group reported hollow 2D layered (HMD) ${ }_{3} \mathrm{SnBr}_{8}$ crystals synthesized by the antisolvent method. These crystals showed bright yellow luminescence with a PL QY of $86 \%$ and were used to fabricate remarkably stable WLEDs by mixing with commercially blue phosphor. ${ }^{25} \mathrm{~A}\left(\mathrm{C}_{18} \mathrm{H}_{35} \mathrm{NH}_{3}\right)_{2} \mathrm{SnBr}_{4} 2 \mathrm{D}$ perovskite film was applied to produce orange LEDs, showing improved device performance than the $2 \mathrm{D}$ analogues, but the usage of toxic and expensive tri- $n$-octylphosphine (TOP) during the synthesis limited its large-scale application. ${ }^{26}$ Recently, for the first time, our group synthesized highly emissive 2D tinhalide (OCTAm) ${ }_{2} \mathrm{SnX}_{4}$ perovskites, in aqueous solution with a PL QY near unity and high stability in air. ${ }^{27}$ We noted that Li's group reported the facile synthesis of $2 \mathrm{D}$ bulk tin-halide $\left(\mathrm{RNH}_{3}\right)_{2} \mathrm{SnBr}_{4}$ perovskites and explored the effect of different carbon chains on 2D organic tin-halide perovskites. ${ }^{28}$

The length of the organic amine chain will affect the transport of carriers, thereby affecting the device performance of 2D tin-halide perovskites. ${ }^{29}$ Herein, we synthesized 2D $\left(\mathrm{RNH}_{3}\right)_{2} \mathrm{SnX}_{4}$ perovskites with high luminescence emission from yellow to red by a hot injection method. $\left(\mathrm{RNH}_{3}\right)$ represents the long-chain amine cation: hexylamine cation $\left(\mathrm{C}_{6} \mathrm{H}_{13} \mathrm{NH}_{3}{ }^{+}\right)$, octylamine cation $\left(\mathrm{C}_{8} \mathrm{H}_{17} \mathrm{NH}_{3}{ }^{+}\right)$, dodecylamine cation $\left(\mathrm{C}_{12} \mathrm{H}_{25} \mathrm{NH}_{3}{ }^{+}\right)$, and oleylamine cation $\left(\mathrm{C}_{18} \mathrm{H}_{35} \mathrm{NH}_{3}{ }^{+}\right)$. For simplicity, we use $\mathrm{C} 6, \mathrm{C} 8, \mathrm{C} 12$, and $\mathrm{C} 18$ to represent $\left(\mathrm{C}_{6} \mathrm{H}_{13} \mathrm{NH}_{3}\right)_{2} \mathrm{SnBr}_{4},\left(\mathrm{C}_{8} \mathrm{H}_{17} \mathrm{NH}_{3}\right)_{2} \mathrm{SnBr}_{4},\left(\mathrm{C}_{12} \mathrm{H}_{25} \mathrm{NH}_{3}\right)_{2} \mathrm{SnBr}_{4}$ and $\left(\mathrm{C}_{18} \mathrm{H}_{35} \mathrm{NH}_{3}\right)_{2} \mathrm{SnBr}_{4}$, respectively, in the figures. Compared with room-temperature synthesis, perovskites synthesized by the hot injection method were more stable. ${ }^{30}$ In addition, we thoroughly discussed the effects of A-site organic cation substitution on their structural and optical properties and stability. The spectral tunability of $2 \mathrm{D}$ tin hybrid perovskites by adjusting the $\mathrm{Br} / \mathrm{I}$ halide ratio was also explored. Furthermore, $\mathrm{Zn}^{2+}$ was introduced as a dopant into the $2 \mathrm{D}\left(\mathrm{C}_{8} \mathrm{H}_{17} \mathrm{NH}_{3}\right)_{2} \mathrm{SnX}_{4}(\mathrm{X}=\mathrm{Br}, \mathrm{I})$ perovskite lattice. Finally, we successfully used the $\mathrm{Zn}^{2+}$-doped $\left(\mathrm{C}_{8} \mathrm{H}_{17} \mathrm{NH}_{3}\right)_{2} \mathrm{SnBr}_{4}$ perovskite as a yellow phosphor to fabricate UV-pumped LEDs. In comparison to previous reports, the differences and significance of the current work are as follows: (i) we used stannous 2-ethylhexanoate instead of the commonly used $\mathrm{TOP}-\mathrm{SnBr}_{2}$ in the high temperature reaction, which could avoid the problem of toxicity and high cost; (ii) all the $\left(\mathrm{RNH}_{3}\right)_{2} \mathrm{SnBr}_{4}$ samples showed bright emission from yellow to orange and exhibited good air stability; (iii) by adjusting the $\mathrm{Br} /$ I ratio, the PL emission peak could be tuned from yellow to red; (iv) better morphology and stability were achieved after $\mathrm{Zn}^{2+}$ doping into $2 \mathrm{D}\left(\mathrm{C}_{8} \mathrm{H}_{17} \mathrm{NH}_{3}\right)_{2} \mathrm{SnX}_{4}$ perovskites; (v) $\mathrm{Zn}^{2+}$-doped $\left(\mathrm{C}_{8} \mathrm{H}_{17} \mathrm{NH}_{3}\right)_{2} \mathrm{SnBr}_{4}$ yellow phosphor with excellent optical properties was used to fabricate UV-pumped LEDs.

\section{Results and discussion}

We adopted a traditional hot-injection approach to synthesize the $2 \mathrm{D}\left(\mathrm{RNH}_{3}\right)_{2} \mathrm{SnBr}_{4}$ perovskites without utilizing the toxic TOP solvent (details are shown in the Experimental section). Typically, oleic acid (OA), alkylamine, and hydrobromic acid ( $\mathrm{HBr}$ ) were dissolved in octadecene (ODE) to form a $\mathrm{RNH}_{3}{ }^{+}-$ halide-precursor solution; while the organic amine was partially protonated to $\mathrm{RNH}_{3}{ }^{+}$through acidification, the rest of the amine and OA molecules acted as dual ligands. After the stannous 2-ethylhexanoate was injected at elevated temperatures, the luminescent $2 \mathrm{D}\left(\mathrm{RNH}_{3}\right)_{2} \mathrm{SnBr}_{4}$ perovskites were precipitated (Scheme 1).

All the as-synthesized $\left(\mathrm{RNH}_{3}\right)_{2} \mathrm{SnBr}_{4}$ perovskites showed periodic diffraction peaks in powder X-ray diffraction (PXRD) patterns (Fig. 1a), which were the characteristics of 2D perovskites. $^{31,32}$ According to Bragg's law, the layer spacing of $2 \mathrm{D}\left(\mathrm{RNH}_{3}\right)_{2} \mathrm{SnBr}_{4}$ perovskites was calculated as $18.1 \AA$ $\left(\left(\mathrm{C}_{6} \mathrm{H}_{13} \mathrm{NH}_{3}\right)_{2} \mathrm{SnBr}_{4}\right), \quad 24.6 \AA \quad\left(\left(\mathrm{C}_{8} \mathrm{H}_{17} \mathrm{NH}_{3}\right)_{2} \mathrm{SnBr}_{4}\right), \quad 33.8 \AA$ $\left(\left(\mathrm{C}_{12} \mathrm{H}_{25} \mathrm{NH}_{3}\right)_{2} \mathrm{SnBr}_{4}\right)$ and $39.6 \AA\left(\left(\mathrm{C}_{18} \mathrm{H}_{35} \mathrm{NH}_{3}\right)_{2} \mathrm{SnBr}_{4}\right)$. The schematic diagrams of the crystal structures of $2 \mathrm{D}\left(\mathrm{RNH}_{3}\right)_{2} \mathrm{SnBr}_{4}$ perovskites are shown in Fig. 1b. A single metal halide
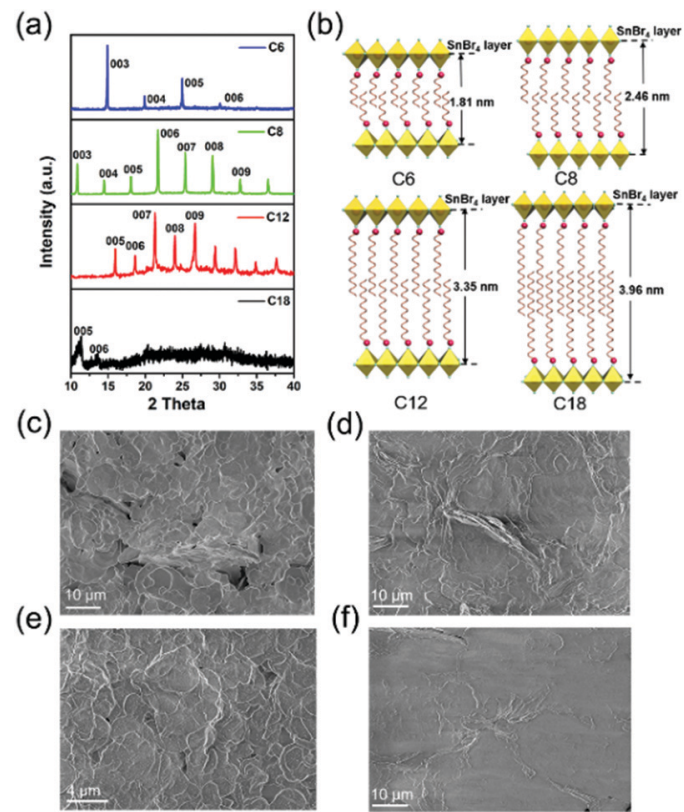

Fig. 1 (a) Powder X-ray diffraction (PXRD) patterns and (b) schematic diagrams of crystal structures for $2 \mathrm{D}\left(\mathrm{RNH}_{3}\right)_{2} \mathrm{SnBr}_{4}$ perovskites. Scanning electron microscopy (SEM) images of 2D $\left(\mathrm{RNH}_{3}\right)_{2} \mathrm{SnBr}_{4}$ perovskites: (c) C6, (d) $\mathrm{C} 8$, (e) $\mathrm{C} 12$, and (f) $\mathrm{C} 18$ (for simplicity, we use $\mathrm{C} 6, \mathrm{C} 8, \mathrm{C} 12$, and $\mathrm{C} 18$ to represent $\left(\mathrm{C}_{6} \mathrm{H}_{13} \mathrm{NH}_{3}\right)_{2} \mathrm{SnBr}_{4},\left(\mathrm{C}_{8} \mathrm{H}_{17} \mathrm{NH}_{3}\right)_{2} \mathrm{SnBr}_{4},\left(\mathrm{C}_{12} \mathrm{H}_{25} \mathrm{NH}_{3}\right)_{2} \mathrm{SnBr}_{4}$, and $\left(\mathrm{C}_{18} \mathrm{H}_{35} \mathrm{NH}_{3}\right)_{2} \mathrm{SnBr}_{4}$ perovskites, respectively). 
(a)

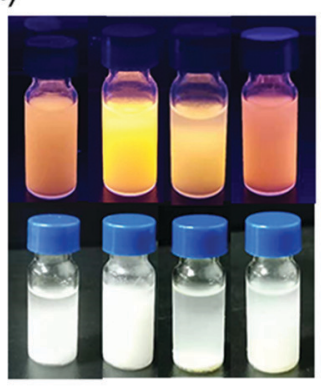

(d)

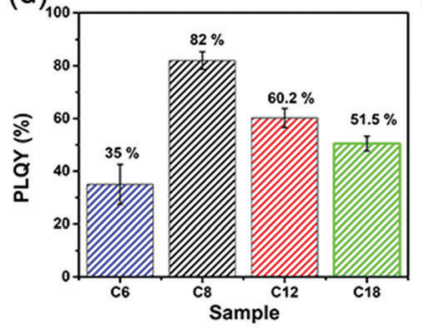

(b)

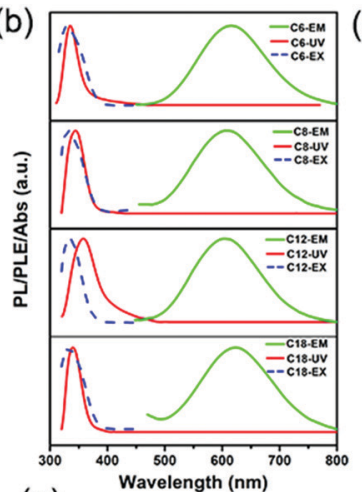

(e)

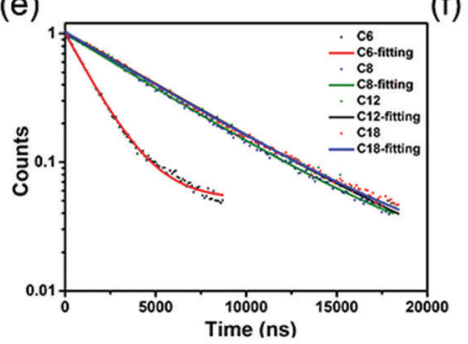

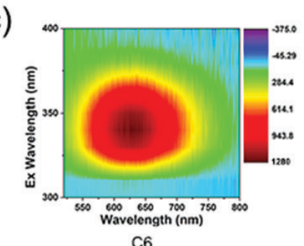

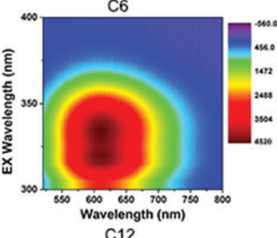

(f)

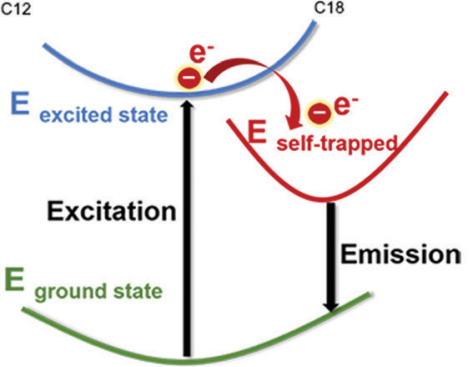

Fig. 2 Optical properties of $2 \mathrm{D}\left(\mathrm{RNH}_{3}\right)_{2} \mathrm{SnBr}_{4}$ perovskites: (a) Photographs of the colloidal suspension at room temperature and under UV light. (b) UVvis absorption, PL emission, and PL excitation spectra. (c) Three-dimensional excitation-emission matrix (EEM) fluorescence spectrum. (d) PL QY and (e) time-resolved PL decay spectra. (f) Schematic of exciton self-trapping in 2D ( $\left.\mathrm{RNH}_{3}\right)_{2} \mathrm{SnBr}_{4}$ perovskites (for simplicity, we use C6, C8, C12, and C18 to represent $\left(\mathrm{C}_{6} \mathrm{H}_{13} \mathrm{NH}_{3}\right)_{2} \mathrm{SnBr}_{4},\left(\mathrm{C}_{8} \mathrm{H}_{17} \mathrm{NH}_{3}\right)_{2} \mathrm{SnBr}_{4},\left(\mathrm{C}_{12} \mathrm{H}_{25} \mathrm{NH}_{3}\right)_{2} \mathrm{SnBr}_{4}$, and $\left(\mathrm{C}_{18} \mathrm{H}_{35} \mathrm{NH}_{3}\right)_{2} \mathrm{SnBr}_{4}$ perovskites, respectively).

octahedral layer is $\sim 6.7 \AA$, so we can infer that two interleaving cation layers occupy spaces of $\sim 11.4 \AA\left(\left(\mathrm{C}_{6} \mathrm{H}_{13} \mathrm{NH}_{3}\right)_{2} \mathrm{SnBr}_{4}\right)$, $\sim 17.9 \AA\left(\left(\mathrm{C}_{8} \mathrm{H}_{17} \mathrm{NH}_{3}\right)_{2} \mathrm{SnBr}_{4}\right), \sim 27.1 \AA\left(\left(\mathrm{C}_{12} \mathrm{H}_{25} \mathrm{NH}_{3}\right)_{2} \mathrm{SnBr}_{4}\right)$, and $\sim 32.9 \AA\left(\left(\mathrm{C}_{18} \mathrm{H}_{35} \mathrm{NH}_{3}\right)_{2} \mathrm{SnBr}_{4}\right)$.

Fourier-transform infrared (FTIR) spectroscopy (Fig. S1, ESI $\dagger$ ) also proved that the $\mathrm{NH}_{3}{ }^{+}$characteristic peak at $3100 \mathrm{~cm}^{-1}$ existed in all the $2 \mathrm{D}\left(\mathrm{RNH}_{3}\right)_{2} \mathrm{SnBr}_{4}$ perovskites. ${ }^{33,34}$ $\mathrm{X}$-Ray photoelectron spectroscopy (XPS) spectra of 2D $\left(\mathrm{C}_{8} \mathrm{H}_{17} \mathrm{NH}_{3}\right)_{2} \mathrm{SnBr}_{4}$ perovskites are shown in Fig. S2 (ESI $\dagger$ ). An obvious peak at $284 \mathrm{eV}$ was related to $\mathrm{C} 1 \mathrm{~s}$; the peak at $400.9 \mathrm{eV}$ was attributed to $\mathrm{N} 1 \mathrm{~s}$; the peaks located at $485.8 \mathrm{eV}$ and 494.1 $\mathrm{eV}$ originated from Sn $3 \mathrm{~d}$ of $\mathrm{Sn}^{2+}$ ions; ${ }^{26,28}$ the peak located at $67.5 \mathrm{eV}$ was attributed to $\mathrm{Br} 3 \mathrm{~d} .{ }^{35}$ According to the integrated peak intensities, the elemental $\mathrm{N}: \mathrm{Sn}: \mathrm{Br}$ ratio of the $2 \mathrm{D}$ $\left(\mathrm{C}_{8} \mathrm{H}_{17} \mathrm{NH}_{3}\right)_{2} \mathrm{SnBr}_{4}$ perovskites was $4.4: 1: 5.6$. The total amount of nitrogen detected comes from alkylamine molecules from the perovskite structure and the surrounding organic protective shell. ${ }^{36} 2 \mathrm{D}\left(\mathrm{RNH}_{3}\right)_{2} \mathrm{SnBr}_{4}$ perovskites with layered morphology were observed in scanning electron microscopy (SEM) (Fig. 1c-f and Fig. S3, ESI + ), which agreed well with the results of XRD (Fig. 1a). The elements of nitrogen, tin, and bromide were distributed homogeneously in all the samples (Fig. S4, ESI $\dagger$ ). The TEM and HAADF-STEM images in Fig. S5 (ESI $\dagger$ ) also indicated the 2D layered structure of $\left(\mathrm{C}_{18} \mathrm{H}_{35} \mathrm{NH}_{3}\right)_{2} \mathrm{SnBr}_{4}$ perovskites. The colloidal suspension of $2 \mathrm{D}\left(\mathrm{RNH}_{3}\right)_{2} \mathrm{SnBr}_{4}$ perovskites in hexane showed yellow to orange emission under $365 \mathrm{~nm}$ UV light as the alkylammonium ligand varies, among which the $\left(\mathrm{C}_{8} \mathrm{H}_{17} \mathrm{NH}_{3}\right)_{2} \mathrm{SnBr}_{4}$ perovskites showed the strongest luminescence (Fig. 2a). The UV-vis absorption, PL excitation, and PL emission spectra of these $\left(\mathrm{RNH}_{3}\right)_{2} \mathrm{SnBr}_{4}$ perovskites are shown in Fig. 2b. $\left(\mathrm{RNH}_{3}\right)_{2} \mathrm{SnBr}_{4}$ perovskites with different alkylammonium cations showed absorption and PL peaks at different wavelengths, as summarized in Table 1. All these perovskites show broadband emission with extremely large full width at half maximum (FWHM) (134-138 nm). The $[F(R) h \nu]^{2}$ versus energy curves are shown in Fig. S6 (ESI $\dagger)$, showing that $2 \mathrm{D}\left(\mathrm{RNH}_{3}\right)_{2} \mathrm{SnBr}_{4}$ perovskites possess direct band gaps of $3.48 \mathrm{eV}\left(\left(\mathrm{C}_{6} \mathrm{H}_{13} \mathrm{NH}_{3}\right)_{2} \mathrm{SnBr}_{4}\right), 3.38 \mathrm{eV}$ $\left(\left(\mathrm{C}_{8} \mathrm{H}_{17} \mathrm{NH}_{3}\right)_{2} \mathrm{SnBr}_{4}\right), 3.20 \mathrm{eV}\left(\left(\mathrm{C}_{12} \mathrm{H}_{25} \mathrm{NH}_{3}\right)_{2} \mathrm{SnBr}_{4}\right)$ and $3.36 \mathrm{eV}$ $\left(\left(\mathrm{C}_{18} \mathrm{H}_{36} \mathrm{NH}_{3}\right)_{2} \mathrm{SnBr}_{4}\right)$. All the samples have relatively large Stokes shifts, i.e. $>260 \mathrm{~nm}$. The shifts of the emission peaks might be attributed to the transient elastic lattice distortions of octahedra which were affected by the different organic cations. ${ }^{37}$ The $2 \mathrm{D}\left(\mathrm{RNH}_{3}\right)_{2} \mathrm{SnBr}_{4}$ perovskites were further studied using three-dimensional excitation-emission matrix (EEM) fluorescence spectroscopy (Fig. 2c). With the change of the excitation wavelength, the emission peaks showed a little shift, indicating that there were no other impurities or additional energy levels in our samples. Fig. 2d illustrates that, with increasing alkyl chain length, the PL QY is enhanced from $35 \%\left(\left(\mathrm{C}_{6} \mathrm{H}_{13} \mathrm{NH}_{3}\right)_{2} \mathrm{SnBr}_{4}\right)$ to $82 \% \quad\left(\left(\mathrm{C}_{8} \mathrm{H}_{17} \mathrm{NH}_{3}\right)_{2} \mathrm{SnBr}_{4}\right)$ initially, but then experienced further reduction to $60.2 \%$ $\left(\left(\mathrm{C}_{12} \mathrm{H}_{25} \mathrm{NH}_{3}\right)_{2} \mathrm{SnBr}_{4}\right)$ and $50.5 \%\left(\left(\mathrm{C}_{18} \mathrm{H}_{35} \mathrm{NH}_{3}\right)_{2} \mathrm{SnBr}_{4}\right)$. The PL QY versus excitation wavelength curves of $2 \mathrm{D}\left(\mathrm{C}_{6} \mathrm{H}_{13} \mathrm{NH}_{3}\right)_{2}$ $\mathrm{SnBr}_{4}$ (a), $\left(\mathrm{C}_{8} \mathrm{H}_{17} \mathrm{NH}_{3}\right)_{2} \mathrm{SnBr}_{4}$ (b), $\left(\mathrm{C}_{12} \mathrm{H}_{25} \mathrm{NH}_{3}\right)_{2} \mathrm{SnBr}_{4} \quad$ (c), and $\left(\mathrm{C}_{18} \mathrm{H}_{35} \mathrm{NH}_{3}\right)_{2} \mathrm{SnBr}_{4}$ (d) perovskites were also investigated (Fig. S7, ESI $\dagger$ ). All these samples showed excitation dependent $\mathrm{PL} \mathrm{QY}$, achieving their highest values at $\left.340 \mathrm{~nm}\left(\left(\mathrm{C}_{6} \mathrm{H}_{13} \mathrm{NH}_{3}\right)_{2} \mathrm{SnBr}_{4},\left(\mathrm{C}_{8} \mathrm{H}_{17} \mathrm{NH}_{3}\right)_{2} \mathrm{SnBr}_{4}\right)\right)$ and $320 \mathrm{~nm}$ $\left.\left(\left(\mathrm{C}_{12} \mathrm{H}_{25} \mathrm{NH}_{3}\right)_{2} \mathrm{SnBr}_{4},\left(\mathrm{C}_{18} \mathrm{H}_{35} \mathrm{NH}_{3}\right)_{2} \mathrm{SnBr}_{4}\right)\right)$. 
Table 1 Summary of the optical properties of $\left(\mathrm{RNH}_{3}\right)_{2} \mathrm{SnBr}_{4}$ perovskites

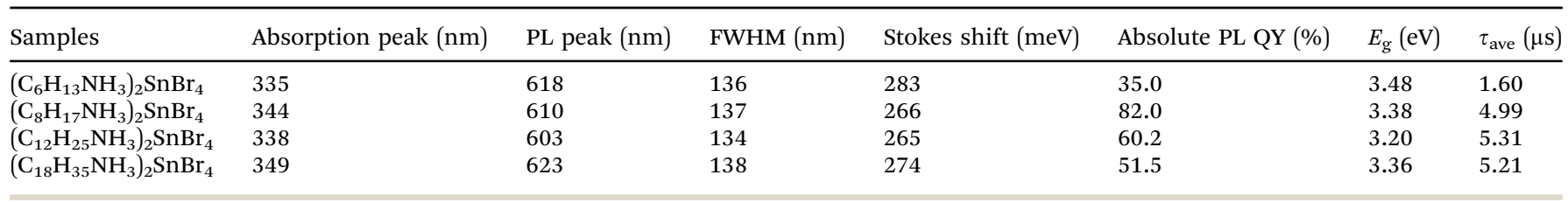

The time-resolved PL decay curves of $2 \mathrm{D}\left(\mathrm{RNH}_{3}\right)_{2} \mathrm{SnBr}_{4}$ perovskites in Fig. 2e could be fitted by a single exponential function with a long lifetime of $1.60-5.31 \mu \mathrm{s}$. To illustrate the internal mechanism between the average PL lifetime and PLQY in various samples, we calculated the radiative $\left(k_{\mathrm{r}}=\mathrm{PLQY} / \tau_{\text {avg }}\right)$ and nonradiative $\left(k_{\mathrm{nr}}=\left(1 / \tau_{\text {avg }}\right)-k_{\mathrm{r}}\right)$ decay rates based on the

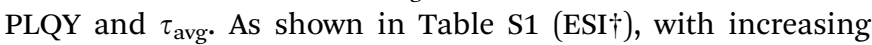
$k_{\mathrm{r}} / k_{\mathrm{nr}}$, the nonradiative pathways were suppressed, and thus the PLQY of $\left(\mathrm{RNH}_{3}\right)_{2} \mathrm{SnBr}_{4}$ increased. ${ }^{28,38-40}$ Table S1 (ESI $\dagger$ ) shows that $\left(\mathrm{C}_{6} \mathrm{H}_{13} \mathrm{NH}_{3}\right)_{2} \mathrm{SnBr}_{4}$ has the lowest $k_{\mathrm{r}} / k_{\mathrm{nr}}$ value of 0.5385 . Therefore, we assumed that there were some non-ignorable non-radiative carrier trapping processes, which led to its lowest PLQY ${ }^{28,41-43}$ The differences in PLQY and lifetime among these $\left(\mathrm{RNH}_{3}\right)_{2} \mathrm{SnBr}_{4}$ indicated that the optical properties were influenced by the distortion of the structure.

In order to investigate the mechanism of broadband emission in our two-dimensional (2D) layered tin halide perovskites, we conducted a comprehensive review of 2D perovskites which also showed broadband emission, large Stokes shifts, and long lifetimes. ${ }^{28,44-47} \mathrm{Li}$ et al. reported the fabrication of 2D $\left(\mathrm{RNH}_{3}\right)_{2} \mathrm{SnBr}_{4}$ perovskites and their density functional theory (DFT) study revealed that these properties originated from a strong phonon coupling in the deformable lattice. ${ }^{28}$ Multi-layered lead iodide perovskites were investigated via temperature-dependent photoluminescence (PL) spectroscopy and transient absorption (TA) spectroscopy. The results proved that the broad emission was related to the electronphonon coupling and structural deformation of the groundstate lattice arising from STEs. ${ }^{47}$ The optical properties obtained in this study were consistent with the literature; therefore, we inferred that the observed broad emission, large Stokes shift, and long lifetimes of our samples stemmed from STEs. As shown in Fig. 2f, when excitons are trapped, the distortion of STEs compared to the ground state broadens the emission. The highly distorted octahedron generates more STEs, resulting in longer PL lifetimes. Fig. S8 (ESI $\dagger$ ) shows the stability curves of $2 \mathrm{D}\left(\mathrm{RNH}_{3}\right)_{2} \mathrm{SnBr}_{4}$ perovskites stored under ambient conditions for 30 days. All these samples exhibited good air stability. In particular, the PL QY of $\left(\mathrm{C}_{18} \mathrm{H}_{35} \mathrm{NH}_{3}\right)_{2} \mathrm{SnBr}_{4}$ perovskites decreased less than $1 \%$ after 30 days. It was obvious that longer alkylammonium chains could protect the $\left[\mathrm{SnBr}_{6}\right]^{-}$octahedral luminescence centre more effectively, which in turn enhanced the stability of the $2 \mathrm{D}\left(\mathrm{RNH}_{3}\right)_{2} \mathrm{SnBr}_{4}$ perovskites. $^{29}$ (a)

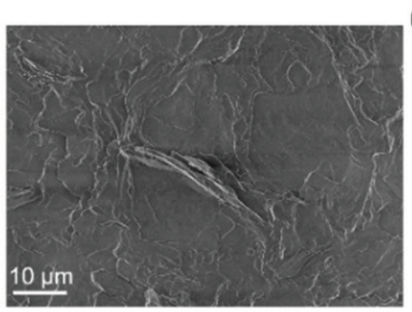

(d)

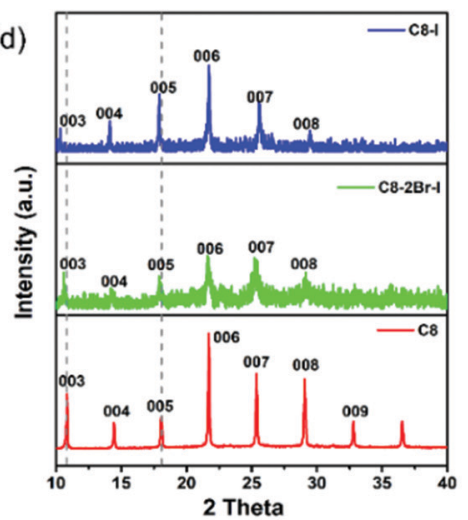

(b)

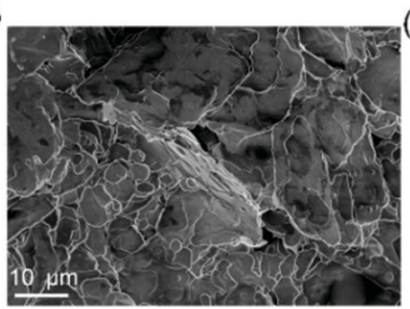

(e)

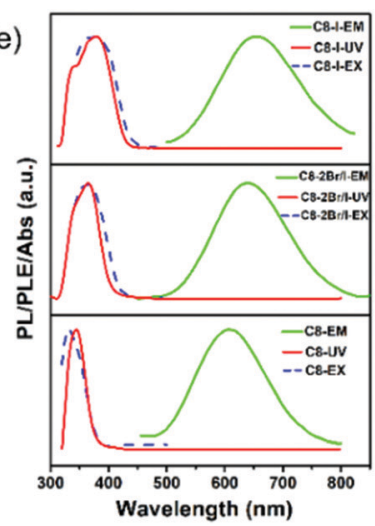

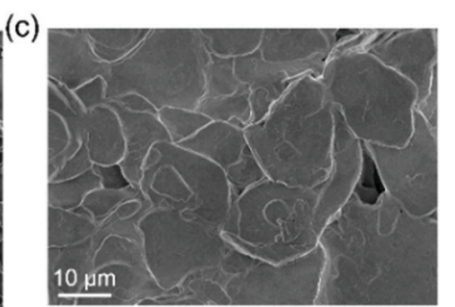

(1)

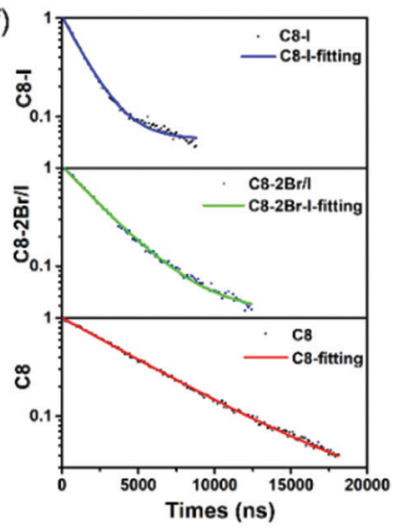

Fig. 3 Scanning electron microscopy (SEM) images of C8 (a), C8-2Br/l (b), and C8-I (c) perovskites. (d) Powder X-ray diffraction (PXRD) patterns of $\left(\mathrm{C}_{8} \mathrm{H}_{17} \mathrm{NH}_{3}\right)_{2} \mathrm{SnX}_{4}$ perovskites $(\mathrm{X}=\mathrm{Br}, 2 \mathrm{Br} / \mathrm{l}$, I). (e) UV-vis absorption, PL emission, and PL excitation spectra of the as-prepared samples. (f) Time-resolved $\mathrm{PL}$ decay spectra of $\left(\mathrm{C}_{8} \mathrm{H}_{17} \mathrm{NH}_{3}\right)_{2} \mathrm{SnX}_{4}$ perovskites (for simplicity, we use $\mathrm{C} 8, \mathrm{C} 8-2 \mathrm{Br} / \mathrm{l}$ and $\mathrm{C} 8$-I to represent $\left(\mathrm{C}_{8} \mathrm{H}_{17} \mathrm{NH}_{3}\right)_{2} \mathrm{SnBr}_{4},\left(\mathrm{C}_{8} \mathrm{H}_{17} \mathrm{NH}_{3}\right)_{2} \mathrm{Sn}\left(2 \mathrm{Br} / \mathrm{I}_{4}\right.$ and $\left(\mathrm{C}_{8} \mathrm{H}_{17} \mathrm{NH}_{3}\right)_{2} \mathrm{Snl}_{4}$ perovskites, respectively). 
Table 2 Summary of the optical properties of $\left(\mathrm{RNH}_{3}\right)_{2} \mathrm{SnX}_{4}$ perovskites

\begin{tabular}{llllll}
\hline & $\begin{array}{l}\text { Absorption } \\
\text { peak (nm) }\end{array}$ & $\begin{array}{l}\text { PL peak } \\
\text { position } \\
(\mathrm{nm})\end{array}$ & $\begin{array}{l}\text { Absolute } \\
\text { PL QY } \\
(\%)\end{array}$ & $\begin{array}{l}\text { Stokes } \\
\text { shift } \\
(\mathrm{nm})\end{array}$ & $\begin{array}{l}\tau_{\text {ave }} \\
(\mu \mathrm{s})\end{array}$ \\
\hline$\left(\mathrm{C}_{8} \mathrm{H}_{17} \mathrm{NH}_{3}\right)_{2} \mathrm{SnBr}_{4}$ & 332 & 610 & 82.0 & 278 & 4.99 \\
$\left(\mathrm{C}_{8} \mathrm{H}_{17} \mathrm{NH}_{3}\right)_{2} \mathrm{Sn}(2 \mathrm{Br} / \mathrm{I})_{4}$ & 363 & 638 & 69.2 & 275 & 2.60 \\
$\left(\mathrm{C}_{8} \mathrm{H}_{17} \mathrm{NH}_{3}\right)_{2} \mathrm{SnI}_{4}$ & 370 & 655 & 33.0 & 285 & 1.41
\end{tabular}

Similar to other halide perovskites, their halide portion of 2D $\left(\mathrm{RNH}_{3}\right)_{2} \mathrm{SnBr}_{4}$ perovskites can also be varied to tune the emission positions. ${ }^{48}$ Various compositions of $\left(\mathrm{C}_{8} \mathrm{H}_{17} \mathrm{NH}_{3}\right)_{2} \mathrm{SnX}_{4}$ perovskites were synthesized by simply tuning the dosage of $\mathrm{HBr}$ and HI proportions. SEM images (Fig. 3a-c and Fig. S9, ESI $\dagger$ ) showed that all the products possessed a $2 \mathrm{D}$ layered morphology. XRD patterns (Fig. 3d) of $\left(\mathrm{C}_{8} \mathrm{H}_{17} \mathrm{NH}_{3}\right)_{2} \mathrm{Sn}(2 \mathrm{Br} / \mathrm{I})_{4}$ and $\left(\mathrm{C}_{8} \mathrm{H}_{17} \mathrm{NH}_{3}\right)_{2} \mathrm{SnI}_{4}$ perovskites also implied periodic diffraction, which was an indication of a 2D layered structure and thus in agreement with the SEM results. In addition, we found that (003) planes showed a slight shift to lower angles from $\left(\mathrm{C}_{8} \mathrm{H}_{17} \mathrm{NH}_{3}\right)_{2} \mathrm{SnBr}_{4}$ to $\left(\mathrm{C}_{8} \mathrm{H}_{17} \mathrm{NH}_{3}\right)_{2} \mathrm{SnI}_{4}$ perovskites due to tin-halide bond expansion. ${ }^{27}$ The FTIR spectra of $2 \mathrm{D}\left(\mathrm{RNH}_{3}\right)_{2} \mathrm{SnX}_{4}$ perovskites are shown in Fig. S10 (ESI $\dagger$ ), and it was pertinent to note that increasing $\mathrm{I}^{-}$ anion did not affect the position and intensity of the functional groups. Similar to lead halide perovskites, when the bromide ion was gradually replaced by the $\mathrm{I}^{-}$anion, the PLE peak red-shifted from 332 to $370 \mathrm{~nm}$ and the PL peak red-shifted from 610 to $655 \mathrm{~nm}$, accompanied by the luminescence change from yellow to red (Fig. 3e). ${ }^{48}$ The UV-vis absorption spectra of $2 \mathrm{D}\left(\mathrm{RNH}_{3}\right)_{2} \mathrm{SnX}_{4}$ perovskites showed that the absorption peak red-shifted from $344 \mathrm{~nm}$ to $370 \mathrm{~nm}$ as the $\mathrm{I} / \mathrm{Br}$ ratio increased. The band gap values were estimated to be $3.38 \mathrm{eV}\left(\left(\mathrm{C}_{8} \mathrm{H}_{17} \mathrm{NH}_{3}\right)_{2} \mathrm{SnBr}_{4}\right)$, $2.89 \mathrm{eV}\left(\left(\mathrm{C}_{8} \mathrm{H}_{17} \mathrm{NH}_{3}\right)_{2} \mathrm{Sn}(2 \mathrm{Br} / \mathrm{I})_{4}\right)$ and $3.17 \mathrm{eV}\left(\left(\mathrm{C}_{8} \mathrm{H}_{17} \mathrm{NH}_{3}\right)_{2} \mathrm{SnI}_{4}\right)$, respectively (Fig. S11, ESI†). Time-resolved PL decay spectra of
$\left(\mathrm{RNH}_{3}\right)_{2} \mathrm{SnX}_{4}$ perovskites are shown in Fig. 3f. All the spectra were fitted with the single exponential decay function and the average PL lifetimes were as follows: $5 \mu \mathrm{s}\left(\left(\mathrm{C}_{8} \mathrm{H}_{17} \mathrm{NH}_{3}\right)_{2} \mathrm{SnBr}_{4}\right)$, $2.6 \mu \mathrm{s}\left(\left(\mathrm{C}_{8} \mathrm{H}_{17} \mathrm{NH}_{3}\right)_{2} \mathrm{Sn}(2 \mathrm{Br} / \mathrm{I})_{4}\right)$, and $1.41 \mu \mathrm{s}\left(\left(\mathrm{C}_{8} \mathrm{H}_{17} \mathrm{NH}_{3}\right)_{2} \mathrm{SnI}_{4}\right)$, which further verified their self-trapping emission mechanism. As expected, the PL QYs of these products were $\left(\mathrm{C}_{8} \mathrm{H}_{17} \mathrm{NH}_{3}\right)_{2} \mathrm{SnBr}_{4}$ (82\%), $\left(\mathrm{C}_{8} \mathrm{H}_{17} \mathrm{NH}_{3}\right)_{2} \mathrm{Sn}(2 \mathrm{Br} / \mathrm{I})_{4} \quad(69.2 \%)$, and $\left(\mathrm{C}_{8} \mathrm{H}_{17} \mathrm{NH}_{3}\right)_{2} \mathrm{SnI}_{4}$ (33\%), respectively, following the trend of the PL decay lifetime. The optical parameters of $\left(\mathrm{RNH}_{3}\right)_{2} \mathrm{SnX}_{4}$ are summarized in Table 2.

$\mathrm{Zn}^{2+}$ doping has been considered as an effective method to achieve highly efficient perovskites. ${ }^{49-51}$ Here, we introduced $\mathrm{Zn}^{2+}$ ions into $2 \mathrm{D}\left(\mathrm{RNH}_{3}\right)_{2} \mathrm{SnX}_{4}(\mathrm{X}=\mathrm{Br}, \mathrm{I})$ perovskites for the first time. Fig. 4a and d show the UV-vis absorption, PL excitation, and PL emission spectra of $\mathrm{Zn}^{2+}$-doped $\left(\mathrm{C}_{8} \mathrm{H}_{17} \mathrm{NH}_{3}\right)_{2} \mathrm{SnBr}_{4}$ and $\mathrm{Zn}^{2+}$-doped $\left(\mathrm{C}_{8} \mathrm{H}_{17} \mathrm{NH}_{3}\right)_{2} \mathrm{SnI}_{4}$ perovskites. After doping, the PL peaks of $\left(\mathrm{C}_{8} \mathrm{H}_{17} \mathrm{NH}_{3}\right)_{2} \mathrm{SnBr}_{4}$ and $\left(\mathrm{C}_{8} \mathrm{H}_{17} \mathrm{NH}_{3}\right)_{2} \mathrm{SnI}_{4}$ obviously shifted from $610 \mathrm{~nm}$ to $580 \mathrm{~nm}$ and from $655 \mathrm{~nm}$ to $630 \mathrm{~nm}$, respectively. The blue-shift of PL peaks might result from lattice contraction. ${ }^{22}$ The XRD patterns of $\mathrm{Zn}^{2+}$-doped $\left(\mathrm{RNH}_{3}\right)_{2} \mathrm{SnX}_{4}$ (Fig. S12, ESI $\dagger$ ) showed that, after doping, no new diffraction peaks appeared. In addition, the diffraction peaks slightly shifted to higher angles, indicating that the doping of zinc did not change the crystallinity of the perovskites but only contracted the lattice. ${ }^{53}$ We included the PL decay of both the undoped sample and doped samples for comparison as shown in Fig. $4 \mathrm{~b}$ and e. The $\mathrm{Zn}^{2+}$-doped $\left(\mathrm{C}_{8} \mathrm{H}_{17} \mathrm{NH}_{3}\right)_{2} \mathrm{SnBr}_{4}$ and $\mathrm{Zn}^{2+}$-doped $\left(\mathrm{C}_{8} \mathrm{H}_{17} \mathrm{NH}_{3}\right)_{2} \mathrm{SnI}_{4}$ perovskites could also be fitted by a single exponential function with a long lifetime of $4.4 \mu \mathrm{s}$ and $1.9 \mu \mathrm{s}$, respectively. The corresponding $\tau_{\text {avg }}$ and $R^{2}$ values are listed in Table S2 (ESI $\dagger$ ); compared with undoped samples, the lifetime of doped samples did not show any obvious change. Interestingly, both
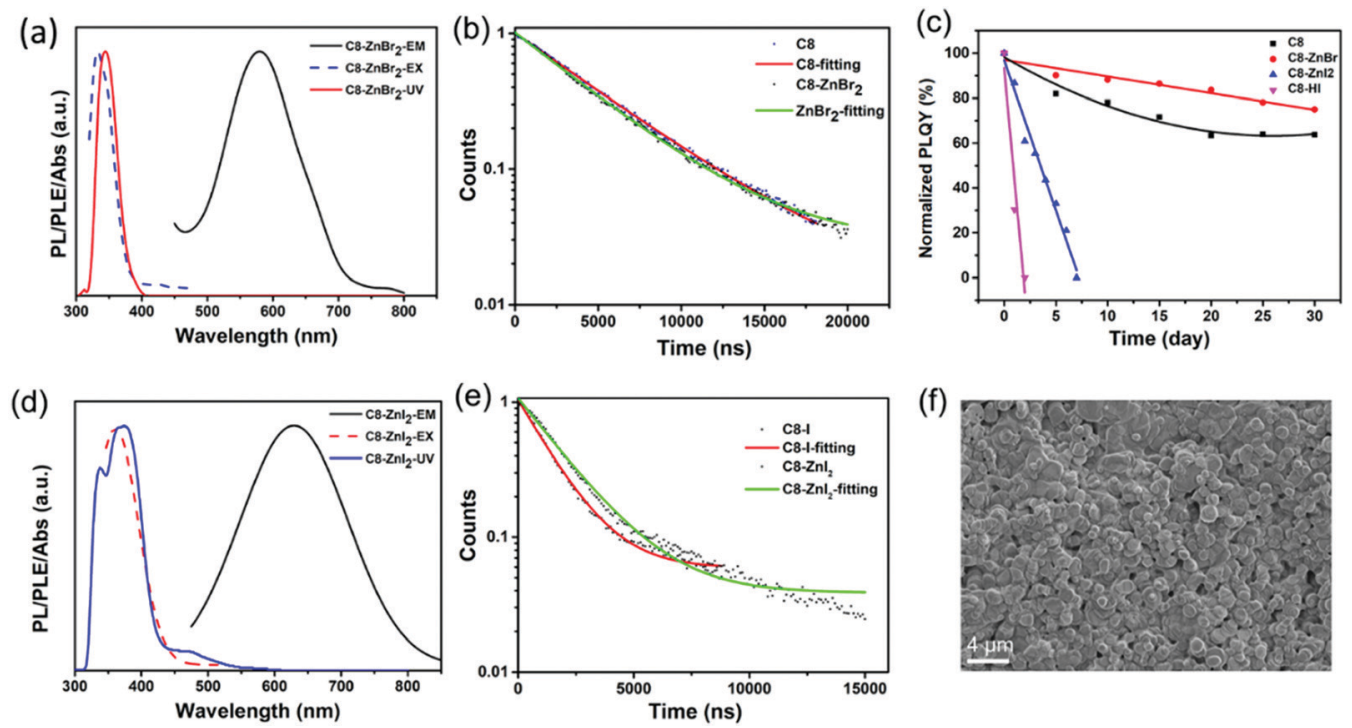

Fig. 4 (a and d) UV-vis absorption, PL emission, and PL excitation spectra of the as-prepared C8 and C8-I doped with $\mathrm{Zn}{ }^{2+}$. (b and e) Time-resolved PL decay and fitting curves. (c) Stability curves displayed by the PL QY of undoped and $\mathrm{Zn}^{2+}$-doped samples. (f) Scanning electron microscopy (SEM) images of $\mathrm{Zn}^{2+}$-doped C8-I samples (for simplicity, we use C8, C8-HI, C8- $\mathrm{ZnBr}_{2}$ and C8- $\mathrm{Znl}_{2}$ to represent $\left(\mathrm{C}_{8} \mathrm{H}_{17} \mathrm{NH}_{3}\right)_{2} \mathrm{SnBr}_{4},\left(\mathrm{C}_{8} \mathrm{H}_{17} \mathrm{NH}_{3}\right)_{2} \mathrm{Snl}_{4}, \mathrm{Zn}^{2+}$-doped $\left(\mathrm{C}_{8} \mathrm{H}_{17} \mathrm{NH}_{3}\right)_{2} \mathrm{SnBr}_{4}$ and $\mathrm{Zn}^{2+}$-doped $\left(\mathrm{C}_{8} \mathrm{H}_{17} \mathrm{NH}_{3}\right)_{2} \mathrm{Snl}_{4}$ perovskites, respectively). 
$\mathrm{Zn}^{2+}$-doped $\left(\mathrm{C}_{8} \mathrm{H}_{17} \mathrm{NH}_{3}\right)_{2} \mathrm{SnBr}_{4}(82 \%$ to $85 \%)$ and $\left(\mathrm{C}_{8} \mathrm{H}_{17} \mathrm{NH}_{3}\right)_{2} \mathrm{SnI}_{4}$ (33\% to $50 \%$ ) perovskites exhibited higher PL QYs compared with undoped ones, which might have resulted from fewer defects and suppressed nonradiative pathways in the doped perovskites. ${ }^{50,54-56}$ We calculated the radiative $\left(k_{\mathrm{r}}=\mathrm{PLQY} / \tau_{\mathrm{avg}}\right)$ and nonradiative $\left(k_{\mathrm{nr}}=\left(1 / \tau_{\mathrm{avg}}\right)-k_{\mathrm{r}}\right)$ decay rates of undoped and doped samples based on the PLQY and $\tau_{\text {avg. The results are }}$ summarized in Table S3 (ESI $\dagger$ ), and prove that, after zincdoping, the nonradiative pathways were inhibited. ${ }^{38-40}$ Furthermore, the alloying significantly improved the stability of $\left(\mathrm{C}_{8} \mathrm{H}_{17} \mathrm{NH}_{3}\right)_{2} \mathrm{SnBr}_{4}$ and $\left(\mathrm{C}_{8} \mathrm{H}_{17} \mathrm{NH}_{3}\right)_{2} \mathrm{SnI}_{4}$ perovskites via lattice contraction (Fig. 4c). ${ }^{52}$ The SEM images (Fig. 4f) showed that $\mathrm{Zn}^{2+}$-doped $\left(\mathrm{C}_{8} \mathrm{H}_{17} \mathrm{NH}_{3}\right)_{2} \mathrm{SnI}_{4}$ perovskites possessed uniform round sheet morphology with an average size of $690 \mathrm{~nm}$. The real elemental composition of $\mathrm{Zn}^{2+} / \mathrm{Sn}^{2+}$ of $\mathrm{Zn}^{2+}$-doped $\left(\mathrm{C}_{8} \mathrm{H}_{17} \mathrm{NH}_{3}\right)_{2} \mathrm{SnBr}_{4}$ and $\left(\mathrm{C}_{8} \mathrm{H}_{17} \mathrm{NH}_{3}\right)_{2} \mathrm{SnI}_{4}$ perovskites were $3 \%$ and $4 \%$, respectively, confirmed by inductively coupled plasma optical emission spectrometry (ICPOES).

The $\mathrm{Zn}^{2+}$-doped $\left(\mathrm{C}_{8} \mathrm{H}_{17} \mathrm{NH}_{3}\right)_{2} \mathrm{SnBr}_{4}$ perovskite was adopted as a yellow phosphor for UV pumped LED fabrication (Fig. 5). Both $\mathrm{Zn}^{2+}$-doped $\left(\mathrm{C}_{8} \mathrm{H}_{17} \mathrm{NH}_{3}\right)_{2} \mathrm{SnBr}_{4}$ in the PS film (Fig. 5a) and the $\mathrm{Zn}^{2+}$-doped $\left(\mathrm{C}_{8} \mathrm{H}_{17} \mathrm{NH}_{3}\right)_{2} \mathrm{SnBr}_{4}$ LED device (Fig. $\left.5 \mathrm{~b}\right)$ showed bright yellow emission. As shown in Fig. 5d, the CIE coordinates, colour rendering index (CRI) and correlated color temperature (CCT) of the LED were measured to be $(0.5060$, 0.4542 ), 75 and $2455 \mathrm{~K}$, respectively. In order to test the stability of the yellow LED, we recorded a series of PL spectral curves by tuning the driving voltage (Fig. 5c). It is worth noting that the PL intensity increased with driving voltage changing from $3 \mathrm{~V}$ to $9 \mathrm{~V}$, without an obvious PL peak shift, indicating its good colour (a)

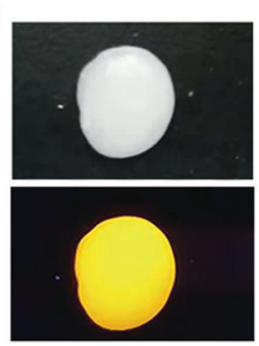

(c)

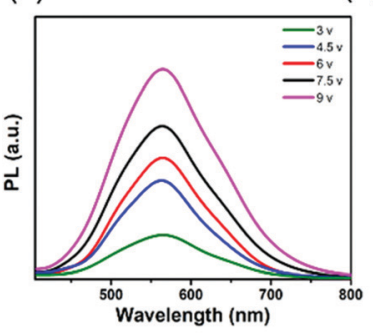

(d)
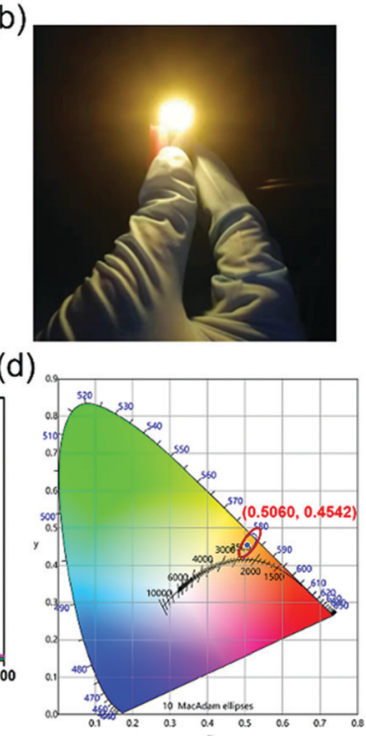

Fig. 5 (a) Images of $\mathrm{Zn}^{2+}$-doped $\left(\mathrm{C}_{8} \mathrm{H}_{17} \mathrm{NH}_{3}\right)_{2} \mathrm{SnBr}_{4}$ yellow phosphor embedded in the PS film under sunlight (top) and $365 \mathrm{~nm}$ UV light (bottom). (b) $365 \mathrm{~nm}$ UV light pumped yellow LED device. (c) PL spectra of a yellow LED obtained by varying the driving voltage. (d) Chromaticity coordinates of $\mathrm{Zn}^{2+}$-doped $\left(\mathrm{C}_{8} \mathrm{H}_{17} \mathrm{NH}_{3}\right)_{2} \mathrm{SnBr}_{4}$ yellow phosphor plotted on the CIE1931 chromaticity chart. stability. These results motivated us to explore further applications including in display backlights.

\section{Conclusions}

In summary, we have demonstrated the synthesis of the leadfree $\left(\mathrm{C}_{6} \mathrm{H}_{13} \mathrm{NH}_{3}\right)_{2} \mathrm{SnBr}_{4},\left(\mathrm{C}_{8} \mathrm{H}_{17} \mathrm{NH}_{3}\right)_{2} \mathrm{SnBr}_{4},\left(\mathrm{C}_{12} \mathrm{H}_{25} \mathrm{NH}_{3}\right)_{2} \mathrm{SnBr}_{4}$ and $\left(\mathrm{C}_{18} \mathrm{H}_{35} \mathrm{NH}_{3}\right)_{2} \mathrm{SnBr}_{4} 2 \mathrm{D}$ perovskites with bright $\mathrm{PL}$ emission properties through a facile hot-injection method using the low-cost and environment-friendly hydrobromic acid and stannous 2-ethylhexanoate as the precursors. Among them, $\left(\mathrm{C}_{8} \mathrm{H}_{17} \mathrm{NH}_{3}\right)_{2} \mathrm{SnBr}_{4}$ perovskites with broad and bright yellow emission centered at $610 \mathrm{~nm}$ achieved the highest PL QY $(82 \%)$. Interestingly, we found that the length of organic amine cations could strongly affect the emission peak, which might be attributed to the transient elastic lattice distortions. Through the incorporation of $\mathrm{Zn}^{2+}$ ions, the $2 \mathrm{D}\left(\mathrm{C}_{8} \mathrm{H}_{17} \mathrm{NH}_{3}\right)_{2} \mathrm{SnBr}_{4}$ showed an enhanced stability and improved morphology uniformity. A yellow-emitting LED was fabricated using the $\mathrm{Zn}^{2+}$ doped $\left(\mathrm{C}_{8} \mathrm{H}_{17} \mathrm{NH}_{3}\right)_{2} \mathrm{SnBr}_{4}$ perovskite. These $2 \mathrm{D}$ perovskites are promising phosphors with potential applications in future solid-state lighting and display technologies.

\section{Experiments}

\section{Chemicals}

1-Octadecene (ODE, Aladdin, GC >90\%), oleic acid (OA, Aladdin, AR, 85\%), hexylamine (Aladdin, AR, 99\%), n-octylamine (Aladdin, AR, 99\%), dodecylamine (Aladdin, AR, 98\%), oleylamine (Aladdin, AR, 80-90\%), hydrobromic acid (HBr, Macklin, $\mathrm{AR}, 48 \mathrm{wt} \%$ in $\mathrm{H}_{2} \mathrm{O}$ ), hydroiodic acid (HI, Aladdin, AR, 55.0$58.0 \%$ with $\leq 1.5 \% \mathrm{H}_{3} \mathrm{PO}_{2}$ ), zinc bromide (Macklin, $\mathrm{AR}$ ), zinc iodide (Aladdin, AR, $\geq 98 \%$ ), stannous 2-ethylhexanoate (Aladdin, AR, 95\%), n-hexane (Macklin, AR, 97\%), and polystyrene (PS, Aladdin) were purchased and used without further purification.

\section{Synthesis of $\left(\mathrm{C}_{8} \mathrm{H}_{17} \mathrm{NH}_{3}\right)_{2} \mathrm{SnX}_{4}$}

To prepare the stannous 2-ethylhexanoate/ODE solution, $370 \mu \mathrm{L}$ stannous 2-ethylhexanoate was added into $740 \mu \mathrm{L}$ ODE, and the solution was mixed well under ultrasonication. In a typical synthesis, ODE $(20 \mathrm{~mL}), \mathrm{OA}(0.4 \mathrm{~mL}), n$-octylamine $(0.4 \mathrm{~mL})$ and $\mathrm{HBr}(163 \mu \mathrm{L})$ were added to a $50 \mathrm{~mL}$ three-neck round bottom flask and degassed at $120{ }^{\circ} \mathrm{C}$ for $2 \mathrm{~h}$. The temperature was increased to $180{ }^{\circ} \mathrm{C}$ under a $\mathrm{N}_{2}$ atmosphere. Then $780 \mu \mathrm{L}$ of the stannous 2-ethylhexanoate/ODE solution was swiftly injected, and the flask was immersed in an ice bath to stop the reaction after $10 \mathrm{~s}$. The crude solution was dispersed in hexane and centrifuged at $10000 \mathrm{rpm}$ for $2 \mathrm{~min}$, and the supernatant was discarded. Finally, a white precipitate of $2 \mathrm{D}$ the $\left(\mathrm{C}_{8} \mathrm{H}_{17} \mathrm{NH}_{3}\right)_{2} \mathrm{SnBr}_{4}$ perovskite was obtained with strong yellow fluorescence under UV light. For the synthesis of $\left(\mathrm{C}_{8} \mathrm{H}_{17} \mathrm{NH}_{3}\right)_{2} \mathrm{Sn}(2 \mathrm{Br} / \mathrm{I})_{4}$ or $\left(\mathrm{C}_{8} \mathrm{H}_{17} \mathrm{NH}_{3}\right)_{2} \mathrm{SnI}_{4}$, the variable compositions were achieved by controlling the ratio of $\mathrm{HBr} / \mathrm{HI}$. 


\section{Synthesis of $\left(\mathrm{RNH}_{3}\right)_{2} \mathrm{SnBr}_{4}$}

To synthesize other $\left(\mathrm{RNH}_{3}\right)_{2} \mathrm{SnBr}_{4}$ perovskites, octylamine was replaced by another organic amine chain with the same molar ratio.

\section{Synthesis of $\mathrm{Zn}^{2+}$-doped $\left(\mathrm{C}_{8} \mathrm{H}_{17} \mathrm{NH}_{3}\right)_{2} \mathrm{SnX}_{4}$}

To prepare $\mathrm{Zn}^{2+}$-doped $\left(\mathrm{C}_{8} \mathrm{H}_{17} \mathrm{NH}_{3}\right)_{2} \mathrm{SnX}_{4}, 10 \% \mathrm{ZnBr}_{2}$ or $\mathrm{ZnI}_{2}$ (by the molar ratio of $\mathrm{Sn}$ ) was added into a mixed solution of ODE $(20 \mathrm{~mL}), \mathrm{OA}(0.4 \mathrm{~mL}), n$-octylamine $(0.4 \mathrm{~mL})$ and $\mathrm{HBr}(163$ $\mu \mathrm{L})$. The subsequent steps were the same as in the synthesis of $\left(\mathrm{C}_{8} \mathrm{H}_{17} \mathrm{NH}_{3}\right)_{2} \mathrm{SnBr}_{4}$.

\section{Fabrication of LEDs}

Yellow $\mathrm{Zn}^{2+}$-doped $\left(\mathrm{C}_{8} \mathrm{H}_{17} \mathrm{NH}_{3}\right)_{2} \mathrm{SnBr}_{4}$ phosphor was well mixed with $25 \%$ polystyrene (PS)-dichloromethane solution. The mixed phosphor of PS paste was dried on a $365 \mathrm{~nm}$ ultraviolet LED chip $(1 \mathrm{~W}, 365 \mathrm{~nm})$ in air to fabricate a yellow LED lamp.

\section{Characterization}

Powder X-ray diffraction (PXRD) was carried out using a Bruker AXS D8 X-ray diffractometer (USA) equipped with monochromated $\mathrm{Cu} \mathrm{K} \alpha$ radiation $(\lambda=1.5418 \AA)$. The diffraction patterns were scanned in the $2 \theta$ range of $10-40$ degrees with a step size of 0.06 at room temperature. X-Ray photoelectron spectroscopy (XPS) was performed using an achromatic $\mathrm{Al} \mathrm{K} \alpha$ source (1486.6 $\mathrm{eV}$ ) and a double pass cylindrical mirror analyzer (ULVAC-PHI 5000 VersaProbe) (Japan). Fourier transform infrared (FTIR) spectroscopy was conducted using a Fourier transform infrared spectrometer (Nicolet NEXUS 870) (USA). The UV-vis absorption spectra were measured using a Shimadzu UV-3600 Plus spectrophotometer (Japan) under ambient conditions. Photoluminescence (PL) measurements were conducted using a Horiba PTI QuantaMaster 400 steady-state fluorescence system (Japan) under ambient conditions. Scanning electron microscopy (SEM) was performed on a Zeiss ULTRA55 electron microscope. The absolute fluorescence quantum yields (PLQYs) were measured using a Horiba PTI QuantaMaster 400 steady-state fluorescence system with an integrated sphere and doublechecked with a Hamamatsu Photonics Quantaurus-QY (model: C11347-11) under ambient conditions. Transmission electron microscopy (TEM) was carried out on an FEI TECNAI G2 F20 and an electron microscope operating at $200 \mathrm{kV}$. The available spectral resolution is about $0.1 \mathrm{~nm}$. Time-resolved PL emission decay curves were collected at room temperature and detected using a low temperature time-resolved fluorescence system (Edinburgh, FLS920) (UK) with the samples being prepared by depositing different perovskites on glass substrates directly. Elemental concentrations of $\mathrm{Zn}^{2+} / \mathrm{Sn}^{2+}$ were analyzed via inductively coupled plasma optical emission spectrometry (ICP-OES) using a Skyray ${ }^{\circledR}$ ICP-3000 instrument.

\section{Author contributions}

Y. L. synthesized the samples, conducted the measurements, and wrote the first draft of the manuscript. A. W. helped with the measurement of the samples and co-drafted the manuscript. J. W., C. W., W. M. and Z. L. revised the manuscript. G. H and S. S. helped with the measurement of the PL decay. J. S. and W. L. helped with the ICP measurements. Z. D. supervised the project. All authors analysed the data and contributed to the discussion.

\section{Conflicts of interest}

There are no conflicts to declare.

\section{Acknowledgements}

This work was supported by the Natural Science Foundation of China (22075129) and the Natural Science Foundation of Jiangsu Province (Grant No. BK20180339 and BZ2018008).

\section{Notes and references}

1 Z. Tan, R. S. Moghaddam, M. L. Lai, P. Docampo, R. Higler, F. Deschler, M. Price, A. Sadhanala, L. M. Pazos, D. Credgington, F. Hanusch, T. Bein, H. J. Snaith and R. H. Friend, Nat. Nanotechnol., 2014, 9, 687-692.

2 M. M. Lee, J. Teuscher, T. Miyasaka, T. N. Murakami and H. J. Snaith, Science, 2012, 338, 643-647.

3 N. J. Jeon, J. H. Noh, W. S. Yang, Y. C. Kim, S. Ryu, J. Seo and S. I. Seok, Nature, 2015, 517, 476-480.

4 M. V. Kovalenko, L. Protesescu and M. I. Bodnarchuk, Science, 2017, 358, 745-750.

5 H. Huang, A. S. Susha, S. V. Kershaw, T. F. Hung and A. L. Rogach, Adv. Sci., 2015, 2, 1500194.

6 L. Protesescu, S. Yakunin, M. I. Bodnarchuk, F. Krieg, R. Caputo, C. H. Hendon, R. X. Yang, A. Walsh and M. V. Kovalenko, Nano Lett., 2015, 15, 3692-3696.

7 W. Liu, Q. Lin, H. Li, K. Wu, I. Robel, J. M. Pietryga and V. I. Klimov, J. Am. Chem. Soc., 2016, 138, 14954-14961.

8 X. Yuan, S. Ji, M. C. De Siena, L. Fei, Z. Zhao, Y. Wang, H. Li, J. Zhao and D. R. Gamelin, Chem. Mater., 2017, 29, 8003-8011.

9 K. P. Marshall, R. I. Walton and R. A. Hatton, J. Mater. Chem. A, 2015, 3, 11631-11640.

10 C. Huo, B. Cai, Z. Yuan, B. Ma and H. Zeng, Small Methods, 2017, 1, 1600018.

11 T. C. Jellicoe, J. M. Richter, H. F. J. Glass, M. Tabachnyk, R. Brady, S. E. Dutton, A. Rao, R. H. Friend, D. Credgington, N. C. Greenham and M. L. Böhm, J. Am. Chem. Soc., 2016, 138, 2941-2944.

12 B. Yang, F. Hong, J. Chen, Y. Tang, L. Yang, Y. Sang, X. Xia, J. Guo, H. He, S. Yang, W. Deng and K. Han, Angew. Chem., Int. Ed., 2019, 58, 2278-2283.

13 B. Yang, X. Mao, F. Hong, W. Meng, Y. Tang, X. Xia, S. Yang, W. Deng and K. Han, J. Am. Chem. Soc., 2018, 140, 17001-17006.

14 S. Liu, B. Yang, J. Chen, D. Wei, D. Zheng, Q. Kong, W. Deng and K. Han, Angew. Chem., Int. Ed., 2020, 59, 21925-21929.

15 W. Yang, F. Igbari, Y. Lou, Z. Wang and L. Liao, Adv. Energy Mater., 2020, 10, 1902584. 
16 G. Xing, M. H. Kumar, W. K. Chong, X. Liu, Y. Cai, H. Ding, M. Asta, M. Grätzel, S. Mhaisalkar, N. Mathews and T. C. Sum, Adv. Mater., 2016, 28, 8191-8196.

17 H. Fang, S. Adjokatse, S. Shao, J. Even and M. A. Loi, Nat. Commun., 2018, 9, 243.

18 F. Wang, J. Ma, F. Xie, L. Li, J. Chen, J. Fan and N. Zhao, Adv. Funct. Mater., 2016, 26, 3417-3423.

19 H. Liang, F. Yuan, A. Johnston, C. Gao, H. Choubisa, Y. Gao, Y. Wang, L. K. Sagar, B. Sun, P. Li, G. Bappi, B. Chen, J. Li, Y. Wang, Y. Dong, D. Ma, Y. Gao, Y. Liu, M. Yuan, M. I. Saidaminov, S. Hoogland, Z.-H. Lu and E. H. Sargent, Adv. Sci., 2020, 7, 1903213.

20 C. Gao, Y. Jiang, C. Sun, J. Han, T. He, Y. Huang, K. Yao, M. Han, X. Wang, Y. Wang, Y. Gao, Y. Liu, M. Yuan and H. Liang, ACS Photonics, 2020, 7, 1915-1922.

21 A. Wang, X. Yan, M. Zhang, S. Sun, M. Yang, W. Shen, P. Wang and Z. Deng, Chem. Mater., 2016, 28, 8132-8140.

22 Z. Tan, J. Li, C. Zhang, Z. Li, Q. Hu, Z. Xiao, T. Kamiya, H. Hosono, G. Niu, E. Lifshitz, Y. Cheng and J. Tang, Adv. Funct. Mater., 2018, 28, 1801131.

23 M. I. Saidaminov, O. F. Mohammed and O. M. Bakr, ACS Energy Lett., 2017, 2, 889-896.

24 L. Lanzetta, J. M. Marin-Beloqui, I. Sanchez-Molina, D. Ding and S. A. Haque, ACS Energy Lett., 2017, 2, 1662-1668.

25 P. Fu, M. Huang, Y. Shang, N. Yu, H. Zhou, Y. Zhang, S. Chen, J. Gong and Z. Ning, ACS Appl. Mater. Interfaces, 2018, 10, 34363-34369.

26 X. Zhang, C. Wang, Y. Zhang, X. Zhang, S. Wang, M. Lu, H. Cui, S. V. Kershaw, W. W. Yu and A. L. Rogach, ACS Energy Lett., 2019, 4, 242-248.

27 A. Wang, Y. Guo, Z. Zhou, X. Niu, Y. Wang, F. Muhammad, H. Li, T. Zhang, J. Wang, S. Nie and Z. Deng, Chem. Sci., 2019, 10, 4573-4579.

28 L. Hou, Y. Zhu, J. Zhu and C. Li, J. Phys. Chem. C, 2019, 123, 31279-31285.

29 F. M. Li, Y. Xie, Y. Hu, M. Long, Y. Zhang, J. B. Xu, M. Qin, X. Lu and M. Liu, ACS Energy Lett., 2020, 5, 1422-1429.

30 A. Dutta, S. K. Dutta, S. Das Adhikari and N. Pradhan, Angew. Chem., Int. Ed., 2018, 57, 9083-9087.

31 C. C. Stoumpos, D. H. Cao, D. J. Clark, J. Young, J. M. Rondinelli, J. I. Jang, J. T. Hupp and M. G. Kanatzidis, Chem. Mater., 2016, 28, 2852-2867.

32 D. H. Cao, C. C. Stoumpos, O. K. Farha, J. T. Hupp and M. G. Kanatzidis, J. Am. Chem. Soc., 2015, 137, 7843-7850.

33 S. Mourdikoudis and L. Liz-Marzán, Chem. Mater., 2013, 25, 1465-1476.

34 W. Xu and T. Wang, Langmuir, 2017, 33, 82-90.

35 Y. Dang, Y. Zhou, X. Liu, D. Ju, S. Xia, H. Xia and X. Tao, Angew. Chem., Int. Ed., 2016, 55, 3447-3450.

36 H. Lin, C. Zhou, Y. Tian, T. Siegrist and B. Ma, ACS Energy Lett., 2018, 3, 54-62.
37 C. Quarti, N. Marchal and D. Beljonne, J. Phys. Chem. Lett., 2018, 9, 3416-3424.

38 B. Yang, J. Chen, F. Hong, X. Mao, K. Zheng, S. Yang, Y. Li, T. Pullerits, W. Deng and K. Han, Angew. Chem., Int. Ed., 2017, 56, 12471-12475.

39 B. Yang and K. Han, Acc. Chem. Res., 2019, 52, 3188-3198.

40 B. Yang, J. Chen, S. Yang, F. Hong, L. Sun, P. Han, T. Pullerits, W. Deng and K. Han, Angew. Chem., Int. Ed., 2018, 130, 5457-5461.

41 J. Tong, J. Wu, W. Shen, Y. Zhang, Y. Liu, T. Zhang, S. Nie, Z. Deng, J. Tong, J. Wu, W. Shen, Y. Zhang, Y. Liu, T. Zhang, S. Nie and Z. Deng, ACS Appl. Mater. Interfaces, 2019, 11, 9317-9325.

42 G. Li, J. Huang, H. Zhu, Y. Li, J. Tang and Y. Jiang, Chem. Mater., 2018, 30, 6099-6107.

43 Z. Liu, Y. Zhang, Y. Fan, Z. Chen, Z. Tang, J. Zhao, Y. Lv, J. Lin, X. Guo, J. Zhang and X. Liu, ACS Appl. Mater. Interfaces, 2018, 10, 13053-13061.

44 M. D. Smith and H. I. Karunadasa, Acc. Chem. Res., 2018, 51, 619-627.

45 L. Mao, Y. Wu, C. C. Stoumpos, B. Traore, C. Katan, J. Even, M. R. Wasielewski and M. G. Kanatzidis, J. Am. Chem. Soc., 2017, 139, 11956-11963.

46 K. Thirumal, W. K. Chong, W. Xie, R. Ganguly, S. K. Muduli, M. Sherburne, M. Asta, S. Mhaisalkar, T. C. Sum, H. S. Soo and N. Mathews, Chem. Mater., 2017, 29, 3947-3953.

47 W. Paritmongkol, E. R. Powers, N. S. Dahod and W. A. Tisdale, J. Phys. Chem. Lett., 2020, 11, 8565-8572.

48 G. Nedelcu, L. Protesescu, S. Yakunin, M. I. Bodnarchuk, M. J. Grotevent and M. V. Kovalenko, Nano Lett., 2015, 15, 5635-5640.

49 M. Que, W. Chen, P. Chen, J. Liu, X. Yin, B. Gao and W. Que, Chem. Phys., 2019, 517, 80-84.

50 J. Li, J. Chen, L. Xu, S. Liu, S. Lan, X. Li and J. Song, Mater. Chem. Front., 2020, 4, 1444-1453.

51 R. Ren, Z. Wang, X. Meng, C. Xu, J. Qiao, W. Sun and K. Sun, ACS Appl. Mater. Interfaces, 2020, 12, 23959-23967.

52 X. Shen, Y. Zhang, S. V. Kershaw, T. Li, C. Wang, X. Zhang, W. Wang, D. Li, Y. Wang, M. Lu, L. Zhang, C. Sun, D. Zhao, G. Qin, X. Bai, W. W. Yu and A. L. Rogach, Nano Lett., 2019, 19, 1552-1559.

53 G. Pan, X. Bai, D. Yang, X. Chen, P. Jing, S. Qu, L. Zhang, D. Zhou, J. Zhu, W. Xu, B. Dong and H. Song, Nano Lett., 2017, 17, 8005-8011.

54 F. Li, Y. Liu, H. Wang, Q. Zhan, Q. Liu and Z. Xia, Chem. Mater., 2018, 30, 8546-8554.

55 W. Zhao, D. Yang, Z. Yang and S. Liu, Mater. Today Energy, 2017, 5, 205-213.

56 W. van der Stam, J. J. Geuchies, T. Altantzis, K. H. W. van den Bos, J. D. Meeldijk, S. Van Aert, S. Bals, D. Vanmaekelbergh and C. de Mello Donega, J. Am. Chem. Soc., 2017, 139, 4087-4097. 